\section{Reaction of Nitric Oxide with Hæmoglobin and Methæmoglobin}

That hæmoglobin reacts with nitric oxide is well known, but there is no agreement in the literature as to the mechanism of this reaction or the nature of the compound thus obtained.

According to Haurowitz ${ }^{1}$, nitric oxide combines only with reduced hæmoglobin in complete absence of oxygen or even in the presence of a reducer (sodium hyposulphite, $\mathrm{Na}_{2} \mathrm{~S}_{2} \mathrm{O}_{4}$ ). Methæmoglobin, according to this author, does not combine directly with nitric oxide, but is reduced by it to hæmoglobin which then combines with more nitric oxide. Anson and Mirsky ${ }^{2}$, on the other hand, consider that nitric oxide combines normally with methæmoglobin. They believe that hæmoglobin in presence of nitric oxide is oxidized to methæmoglobin, which then forms the nitric oxide compound. However, their experiments, consisting in injection of hæmoglobin by means of a syringe into a tonometer containing a mixture of nitrogen and nitric oxide, do not exclude the possibility of introducing dissolved oxygen, the latter giving rise to nitrogen dioxide, which may be responsible for oxidation of hæmoglobin to methæmoglobin.

Careful study of these reactions has convinced us that both these interpretations are only partly correct. All our experiments have been carried out in modified Thunberg tubes which received 3 c.c. of 0.5 per cent solution of hæmoglobin or methæmoglobin at $p \mathrm{H} 6 \cdot 5$, unless otherwise stated. The tubes were evacuated, washed several times with pure nitrogen, and filled with pure nitric oxide. According to the experiment, the hollow stoppers of the tube may receive various reagents which can be mixed with the contents of the tubes.

I. Reaction between Nitric Oxide and Hcemoglobin.

(1) Solutions of oxyhæmoglobin reduced in Thunberg tubes to hæmoglobin by evacuation, when mixed with nitric oxide, turn distinctly red and show two wide and somewhat diffuse bands at $574.5 \mathrm{~m} \mu$ and $536 \mathrm{~m} \mu$.

(2) The same result is obtained in presence of an excess of sodium hyposulphite added at different stages of the reaction.

(3) This compound is very stable and is not decomposed by the addition of a great excess of sodium sulphite or by washing on an ultrafilter membrane.

(4) Potassium ferricyanide added to this compound after removal of excess of nitric oxide only slowly oxidizes it to acid methæmoglobin.

All this confirms Haurowitz's view that the reduced hæmoglobin combines with nitric oxide forming $\mathrm{NO}-\mathrm{Hb}$ compound.

II. Reaction between Nitric Oxide and Methcemoglobin.

(1) An acid solution of methæmoglobin completely free from oxygen mixed in a Thunberg tube with pure nitric oxide rapidly turns red and its absorption spectrum is replaced by two bands at $568 \mathrm{~m} \mu$ and $531 \mathrm{~m} \mu$. These bands are, however, more distinct than those of NO-hæmoglobin and lie 50-60 A. nearer the blue end of the spectrum.

(2) This compound is obtained in the presence of a great excess of potassium ferricyanide.

(3) A solution of acid methæmoglobin, before it is treated as in experiment 1 , is mixed with $10 \mathrm{mgm}$. of sodium sulphite. When this solution is shaken with pure nitric oxide, the bands of methæmoglobin are rapidly replaced by the two bands at 568 and $531 \mathrm{~m} \mu$. On standing a minute or two, the colour and the absorption spectrum revert to those of acid methæmo. globin. This reversion can be repeated several times. Sulphite, on combining with dissolved nitric oxide, liberates acid methæmoglobin.

(4) A Thunberg tube with acid methæmoglobin and a little potassium cyanide in the hollow stopper is treated as in experiment 1 . When the red com. pound with two absorption bands is formed, the cyanide is mixed with the solution and the absorption spectrum of NO-methæmoglobin is replaced by that of KCN-methæmoglobin.

(5) A similar experiment carried out with sodium fluoride instead of potassium cyanide gives only a partial formation of fluoride methæmoglobin. The incomplete reaction in this case is due to the com. paratively low affinity of fluoride for methæmoglobin.

(6) If methæmoglobin is treated with nitric oxide at $p \mathrm{H} 5.6$ and the tube is evacuated immediately the compound is formed, the NO-compound is almost completely reversed to methæmoglobin.

All these experiments clearly demonstrate that methæmoglobin forms with nitric oxide an easily reversible NO-MHb compound. This compound is, however, very unstable. Its absorption bands gradu. ally become diffuse and move towards the red end of the spectrum. The NO-MHb, soon after its formation, is gradually transformed into a compound which is indistinguishable from $\mathrm{NO}-\mathrm{Hb}$, and this change is accelerated if the nitric oxide in the tube is replaced by nitrogen. The fact that this transformation is greatly accelerated on addition of a reducer (sodium hyposulphite) shows that NO-MHb in complete absence of oxygen undergoes reduction to $\mathrm{NO}-\mathrm{Hb}$.

Nitric oxide combines therefore with hæmoglobin (NO-Hb) and methæmoglobin (NO-MHb). With hæmoglobin it forms a very stable compound from which free hæmoglobin cannot be easily recovered. With methæmoglobin, however, it forms an easily reversible compound which is not stable and which, on standing, undergoes reduction to $\mathrm{NO}-\mathrm{Hb}$.

$\begin{array}{cl}\text { Molteno Institute, } & \text { D. KEILIN. } \\ \text { University, Cambridge. } & \text { E. F. HARTree. }\end{array}$

${ }^{1}$ Haurowitz, F., Z. physiol. Chem., 138, 68 (1924); 151, 130 (1926).

${ }^{2}$ Anson, M.L. and Mirsky, A.E., J. Physiol., 60, 100 (1925).

\section{Aldehyde Mutase}

IT is generally believed that aldehyde mutase (the enzyme which catalyses the dismutation of aldehydes in accordance with reaction (1)) is identical with aldehyde oxidase, which oxidizes aldehydes in accordance with reaction (2):

(1) $\mathrm{R}-\mathrm{CHO}+\mathrm{R}-\mathrm{CHO}+\mathrm{H}_{2} \mathrm{O}=\mathrm{R}-\mathrm{COOH}+\mathrm{R}-\mathrm{CH}_{2} \mathrm{OH}$ (2) $\mathrm{R}-\mathrm{CHO}+\mathrm{A} \quad+\mathrm{H}_{2} \mathrm{O}=\mathrm{R}-\mathrm{COOH}+\mathrm{AH}_{2}$

where $A$ may be $\mathrm{O}_{2}$, methylene blue or some other 'hydrogen acceptor'. Wieland ${ }^{1}$ suggests that the oxidase normally uses a hydrogen acceptor to produce an oxidation of the aldehyde, but when no other acceptor is present it uses a second molecule of aldehyde as acceptor, reducing it to alcohol and so producing a dismutation of aldehyde (reaction 1).

We find, however, that aldehyde mutase and aldehyde oxidase are two distinct enzymes which can be obtained separately. Oxidase preparations made from milk by the methods of Dixon and Thurlow or Dixon and Kodama ${ }^{3}$ are very active in catalysing the oxidation of aldehydes by oxygen or by methylene blue, but we can detect no trace of dismutation of 